University of Nebraska - Lincoln

DigitalCommons@University of Nebraska - Lincoln

\title{
Chloroplast DNA and Nuclear DNA Content Variations among Cultivars of Switchgrass, Panicum virgatum $\mathrm{L}$.
}

\author{
Sherry J. Hultquist \\ University of Nebraska-Lincoln \\ Kenneth P. Vogel \\ University of Nebraska-Lincoln, kvogel1@unl.edu \\ D. J. Lee \\ University of Nebraska-Lincoln \\ K. Arumuganathan \\ University of Nebraska-Lincoln \\ S. Kaeppler \\ University of Nebraska-Lincoln, smkaeppl@wisc.edu
}

Follow this and additional works at: https://digitalcommons.unl.edu/usdaarsfacpub

Hultquist, Sherry J.; Vogel, Kenneth P.; Lee, D. J.; Arumuganathan, K.; and Kaeppler, S., "Chloroplast DNA and Nuclear DNA Content Variations among Cultivars of Switchgrass, Panicum virgatum L." (1996). Publications from USDA-ARS / UNL Faculty. 1896.

https://digitalcommons.unl.edu/usdaarsfacpub/1896

This Article is brought to you for free and open access by the U.S. Department of Agriculture: Agricultural Research Service, Lincoln, Nebraska at DigitalCommons@University of Nebraska - Lincoln. It has been accepted for inclusion in Publications from USDA-ARS / UNL Faculty by an authorized administrator of DigitalCommons@University of Nebraska - Lincoln. 


\title{
Chloroplast DNA and Nuclear DNA Content Variations among Cultivars of Switchgrass, Panicum virgatum L.
}

\author{
Sherry J. Hultquist, K. P. Vogel,* D. J. Lee, K. Arumuganathan, and S. Kaeppler
}

\begin{abstract}
Switchgrass, Panicum virgatum L., is a native, cross-pollinated, morphologically diverse species with an array of ploidy levels and ecotypes. Switchgrass is found throughout most of the USA and Canada, primarily east of the Rocky Mountains and south of Hudson Bay. The objective of this research was to determine if chloroplast DNA (cpDNA) restriction fragment length polymorphisms (RFLPs) occur among switchgrass cultivars and experimental strains that differ in ploidy level or ecotype classification. Eighteen switchgrass cultivars or experimental strains representative of reported ecotypes, ploidy levels, and the geographical range of switchgrass were surveyed for cpDNA polymorphisms by means of four restriction endonucleases and 20 sorghum cpDNA probes. One polymorphism was detected which was associated with the lowland-upland ecotype classification. The lowland cultivars contained a restriction site change that was not present in the upland cultivars. The two cytotypes discovered have been designated as the $U$ (upland) or $L$ (lowland) cytotype. The lowland cultivars had $3 \mathrm{pg}$ DNA/nuclei as measured by flow cytometry while the upland types had either 3 or 6 pg DNA/nuclei. There were no cpDNA polymorphisms among the upland cultivars regardless of ploidy level as measured by DNA content. These results demonstrate that cpDNA differs among switchgrasses and that this variation is associated with ecotype variation but not with nuclear DNA content.
\end{abstract}

$S^{n}$ WITCHGRass (Panicum virgatum L.) is a North American, warm-season, cross-pollinated perennial grass that has become increasingly important in the USA for use in pastures, rangelands, and as a potential biomass fuel crop. There is substantial variation among native switchgrasses for many morphological and physiological traits (Eberhardt and Newell, 1959; McMillan and Weiler, 1959; Cornelius and Johnston, 1941). The reported polyploid series in switchgrass ranges from diploid $(2 n=18)$ to duodecaploid $(2 n=108)$ (Church, 1940; Nielson, 1944; McMillan and Weiler, 1959; Riley and Vogel, 1982). Barnett and Carver (1967) reported that switchgrass plants in the lowland river bottoms (lowland ecotype) of central Oklahoma were predominantly tetraploids and that plants in the upland areas (upland ecotype) were predominantly hexaploids and octoploids. Plants of the upland ecotype are described as fine-stemmed, having varying amounts of pubescence on the leaf blades, semidecumbent, and broad based, standing 92 to $152 \mathrm{~cm}$ in

S.J. Hultquist, D.J. Lee, and S. Kaeppler, Dep. of Agronomy, Univ. of Nebraska, Lincoln, NE; K.P. Vogel, USDA-ARS, 344 Keim Hall, Univ. of Nebraska, P.O. Box 830937, Lincoln, NE 68583-0937 and Center for Grassland Studies, Univ. of Nebraska, Lincoln, NE; and K. Arumuganathan, Center for Biotechnology, Univ. of Nebraska, Lincoln, NE 68583 0665. The reported research is from a dissertation submitted by the senior author (Sherry Jean Hulquist Elmore) in partial fulfillment of the requirements for a Ph.D. degree at the University of Nebraska. The research was funded in part by the U.S. Dept. of Energy's Biomass Fuels program via Oak Ridge National Laboratory, USDA-ARS, and the University of Nebraska. Contract no. DE-A 105-900R21954. Journal series no. 11278. Nebraska Agricultural Experiment Station. *Corresponding author (agro012@unlvm.unl.edu).

Published in Crop Sci. 36:1049-1052 (1996). height. Lowland plants are described as erect, coarse stemmed, glabrous, more robust, and found in bunches, standing 61 to $305 \mathrm{~cm}$ in height (Newell and Eberhardt, 1961; Porter, 1966; Barnett and Carver, 1967). Barnett and Carver (1967) and Brunken and Estes (1975) suggested that the lowland and the upland types were genetically distinct populations.

Upland cultivars such as Blackwell and Trailblazer are used primarily for pastures while lowland cultivars such as Kanlow and Alamo appear to have the most potential for use as biomass fuel plants and for wetland restoration. Switchgrass is cross-pollinated and largely self-incompatible (Moser and Vogel, 1995). Switchgrass cultivars have been developed by direct increase of outstanding germplasm accessions or by development of synthetic cultivars via population improvement or other breeding methods (Moser and Vogel, 1995). Because of their sexual mode of reproduction, all switchgrass cultivars are heterogenous populations of individuals. Ploidy levels of some cultivars have been reported (Table 1). Prior to this research, no genetic markers had been developed for switchgrass.

Chloroplast DNA markers have potential for assessing relationships with plant species or ecotypes (Soltis et al., 1992). The chloroplast genome is usually maternally inherited with the mitochondrial genome and hence a single cpDNA RFLP can serve as a marker for the entire cytoplasm. The evolution and domestication of several crop plants has been investigated when intraspecific cpDNA variation has been detected (Laurent et al., 1993; Neale et al., 1986). Chloroplast DNA markers have also provided insights into the derivation of polyploids in several species (Soltis et al., 1992). Therefore cpDNA markers could be useful in understanding relationships among switchgrasses.

The objective of this research was to determine if cpDNA restriction fragment length polymorphisms occur in switchgrasses differing in ploidy level or ecotype classification.

\section{MATERIALS AND METHODS}

\section{Plant Materials}

Fifteen switchgrass cultivars and three experimental strains, Pangburn, PMT-279, and PMT-785 (Table 1), representing a broad geographical range of origin were used in this research. The cultivars included both upland and lowland ecotypes, and cultivars that had been previously identified in the literature as tetraploids $(2 n=36)$, hexaploids $(2 n=54)$, or were unclassified for ploidy level or ecotype. Seeds were planted in flats in the greenhouse, and tissue was harvested from pooled seedlings when the seedlings were approximately $10 \mathrm{~cm}$ in height. An entire flat of seedlings were harvested together and combined to form the pooled samples. Ten seedlings from each flat were

Abbreviations: cpDNA, chloroplast DNA; RFLP, restriction fragment length polymorphism; $U$, upland; $L$, lowland. 
Table 1. Cultivars of Panicum virgatum, their reported ploidy level, cellular DNA content, reported ecotype classification, origin (germplasm collection area), and cpDNA banding pattern.

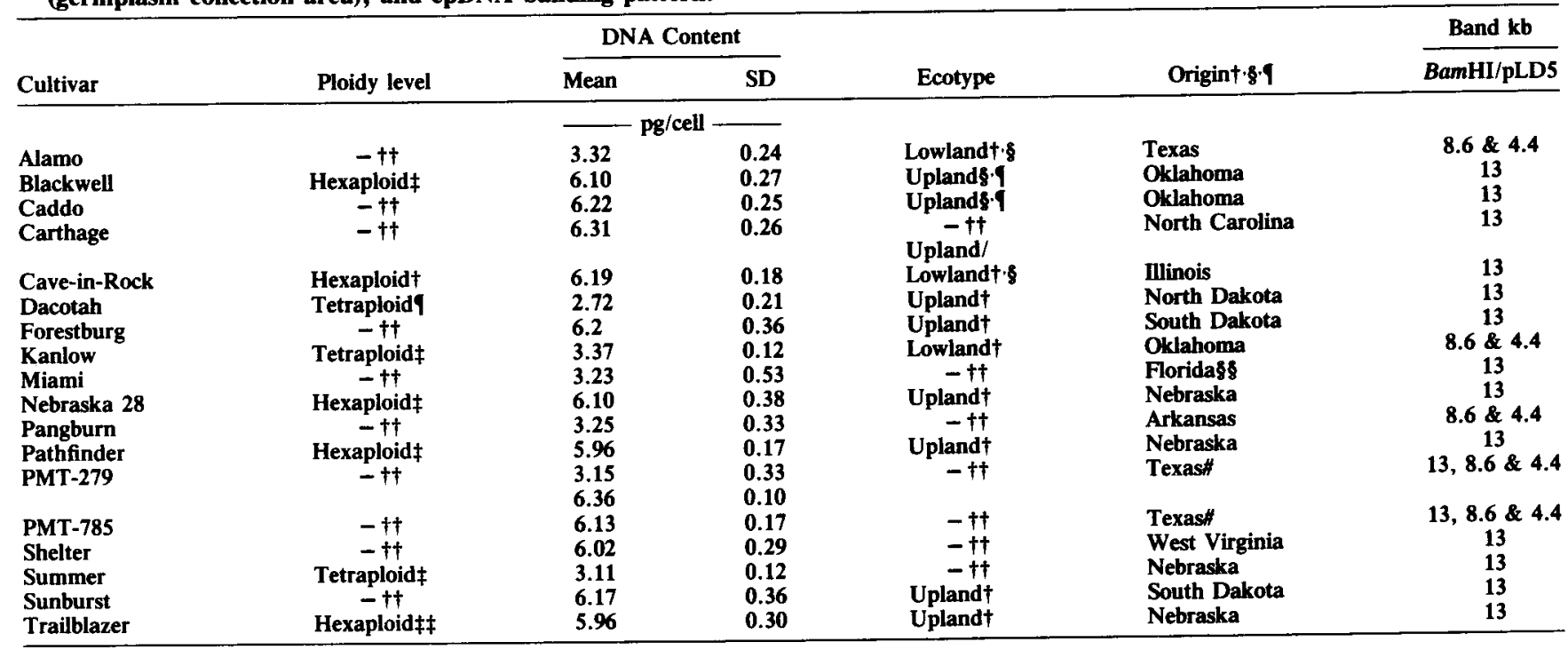

+ Moser and Vogel, 1995.

$\ddagger$ Riley and Vogel, 1982.

8 Everett, 1991 .

1 Alderson and Sharp, 1994.

\# Mark Hussey, 1994, personal communications.

†† No information available.

¥ Vogel et al., 1991.

8 Plant Materials Center, 1994 and 1995, personal communication.

then planted into plots at Lincoln, NE. The field study was a randomized complete block design with two replications with a plot a single row of 10 plants spaced $1.1 \mathrm{~m}$ apart. Flow cytometry analysis was used to determine nuclear DNA content for verification of ploidy level. The analysis was conducted on five plants per row of each cultivar in both replications. One plant in each row was sampled twice to estimate the precision of the flow cytometry analysis. Seedlings of PMT-785 did not survive in the field planting so seedlings grown in the greenhouse were used for flow cytometry analyses for this strain.

\section{RFLP Procedures}

Leaf tissue was freeze-dried and ground by means of liquid nitrogen, silica sand, and a mortar and pestle. Total DNA was extracted following a modified version of Saghai-Maroof et al. (1984). Approximately $5 \mu \mathrm{g}$ of DNA was digested with the restriction enzymes BamHI, EcoRI, EcoRV, and HindIII. The fragmented DNA was resolved on a $8 \mathrm{~g} \mathrm{~L}^{-1}$ agarose gel by electrophoresis. The gel was run overnight, approximately $17 \mathrm{~h}$.

The digested and separated DNA was transferred onto $\mathrm{Hy}$ bond-N nylon membrane (Amersham Corp., Arlington Heights, IL) by a neutral transfer Southern blotting method (Reed and Mann, 1985). The DNA was hybridized with 20 separate sorghum chloroplast DNA probes, representing approximately $52 \%$ of the sorghum chloroplast genome (Dang and Pring, 1986). These cpDNA probes were labeled using the Genius Kit (Boehringer Mannheim Biochemicals, Indianapolis, $\mathrm{IN}^{1}$ ) method of non-radioactive labeling. The pattern of restriction fragments homologous to the 20 sorghum cpDNA probes revealed the cpDNA genotype of each cultivar.

${ }^{1}$ Names of products are included for the benefit of the reader and do not imply endorsement by the USDA or the Univ. of Nebraska.

\section{Flow Cytometry}

Procedures described by Arumuganathan and Earle (1991) were used to determine DNA content per cell. In brief approximately $50 \mathrm{mg}$ of fresh leaf tissue was excised from individual plants and placed on ice in a sterile $35-\times 10-\mathrm{mm}$ plastic petri dish. The tissue was chopped into 0.25 - to $1.0-\mathrm{mm}$ segments in $1 \mathrm{~mL}$ of solution $\mathrm{A}$ [24 mL $\mathrm{MgSO}_{4}$ buffer (ice-cold); 25 $\mathrm{mg}$ dithiothreitol; $500 \mu \mathrm{L}$ propidium iodide stock $(5.0 \mathrm{mg}$ propidium iodide in $1.0 \mathrm{~mL}$ deionized, distilled $\left.\mathrm{H}_{2} \mathrm{O}\right) ; 625 \mu \mathrm{L}$

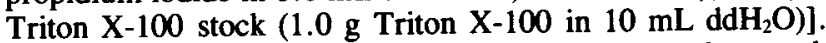
The homogenate was filtered through a $33-\mu \mathrm{m}$ nylon mesh into a mico-centrifuge tube and centrifuged at high speed for 15 to $20 \mathrm{~s}$. The supernatant was discarded, the pellet was resuspended in $400 \mu \mathrm{L}$ of solution $B$ [ $7.5 \mathrm{~mL}$ solution $A ; 17.5$ $\mu \mathrm{L}$ RNAse (DNAse free)] and incubated for $15 \mathrm{~min}$ at $37^{\circ} \mathrm{C}$ before flow cytometric analyses. The prepared material was analyzed in the University of Nebraska Flow Cytometry Core Research Facilities by Dr. K. Arumuganathan using the Coulter EPICS V flow cytometer (Coulter Corporation, Miami). The propidium iodide stained samples were excited with a $120-\mathrm{mW}$ Coherent Innova 300-5 Argon ion laser (Coherent Innova, Palo Alto, CA) at $488 \mathrm{~nm}$. Red fluorescence was collected through 457- to 502-nm laser blocking filter and 590-nm long pass absorbance filter. Flow cytometric analysis of integral peak and log fluorescence and forward scatter was done as described by Arumuganathan and Earle (1991). The mean DNA content per plant was based on 1000 nuclei. The standard used for comparison was 'Stark' spring diploid barley, for which the DNA content was known.

\section{RESULTS AND DISCUSSION}

One hundred twenty-two fragments were generated by the four enzymes and 20 sorghum cpDNA probes. The only probe-enzyme combination to detect a polymor- 
phism among the cultivars was BamHI/pLD 5 (Figure 1). The sorghum cpDNA probe pLD 5 contains the gene for the large subunit of ribulose-1,5-bisphosphate carboxylase (Dang and Pring, 1986). A 13-kb fragment was found in 15 accessions (Blackwell, Caddo, Carthage, Cave-in-Rock, Dacotah, Forestburg, Miami, Nebraska 28, Pathfinder, PMT-279, PMT-785, Shelter, Summer, Sunburst, and Trailblazer), while 8.6- and 4.4-kb fragments were detected in five accessions (Alamo, Kanlow, Pangburn, PMT-279, and PMT-785). The polymorphism appears to be the result of a restriction endonuclease site gain-loss. Therefore, this single restriction site change can be used to identify two cytoplasmic types.

The two experimental strains, PMT-279 and PMT785 , showed a mixture of the two banding patterns (Fig. 1). These strains are synthetic populations formed by pooling germplasm accessions (Mark A. Hussey, 1994, Texas AM University, personal communication). Both cpDNA genotypes are apparently represented by plants in these populations.

Cave-in-Rock has been classified as either lowland (Everett, 1991) or upland-lowland type (Moser and Vogel, 1995) since it is intermediate in morphological characteristics in comparison to distinct lowland types such as Kanlow and upland types such as Pathfinder. Our results indicate that the cytotype of Cave-in-Rock is the same as upland ecotypes typified by Pathfinder and Blackwell.

In the flow cytometry analyses, the duplicate samples on the individual plants of each strain did not differ at $\alpha=0.05$ using a two-tailed $t$ test. The DNA content of the reported tetraploid cultivars was approximately 3 $\mathrm{pg} /$ nucleus and the cultivars reported to be hexaploid had approximately $6 \mathrm{pg} /$ nucleus. The DNA content is consistent with reported chromosome numbers of hexaploid cultivars only if switchgrass has genomes differing in chromosome size. If the genomes of switchgrass are similar in size, plants with 6 pg DNA/nuclei would be expected to be octaploids, particularly if switchgrass is an autopolyploid. Cytogenetic studies are currently in progress to resolve this quandary $(\mathrm{K}$. Lu, S. Kaeppler, K.P. Vogel, 1995, personal communication). A mixture of ploidy levels was detected among plants of the experimental strain PMT 279 (Table 1). This indicates that when this strain was formed, plants differing in both ploidy level and cytotype were pooled.

The 18 cultivars strains used in this study are representative of the reported ploidy level, geographic and morphological or ecotypic diversity in available elite switchgrass germplasm. The cpDNA genotypes did not separate according to nuclear DNA content nor geographical location; however, they were associated with the lowland-upland ecotype groupings of these cultivars (Everett, 1991; Moser and Vogel, 1995). Cultivars previously classified as lowland ecotypes had the additional BamHI restriction site in the pLD 5 region while cultivars previously classified as upland ecotypes lacked this site. Previous reports based on phenotypic observations have postulated that upland and lowland ecotypes are genetically distinct populations (Porter, 1966; Barnett and Carver, 1967; Brunken and Estes, 1975). The cpDNA polymorphism detected in this study can be used to genetically classify germplasms as U (upland) or L (lowland) cytotypes. Further analysis of a larger set of upland and lowland populations will indicate how consistent the association of this restriction site change is with ecotype classification by morphological characteristics. The morphological characterization of switchgrasses such as Miami, Pangburn, and the two PMT strains will have to be done at a southern location since switchgrass growth and morphological development is affected by photoperiod (Moser and Vogel, 1995). Southern strains also often winter kill at northern latitudes.

The association of the cpDNA marker detected in this study with the upland and lowland ecotype designation of switchgrass populations supports the hypothesis that the two ecotypes represent unique germplasm pools. The production of fertile offspring between upland and

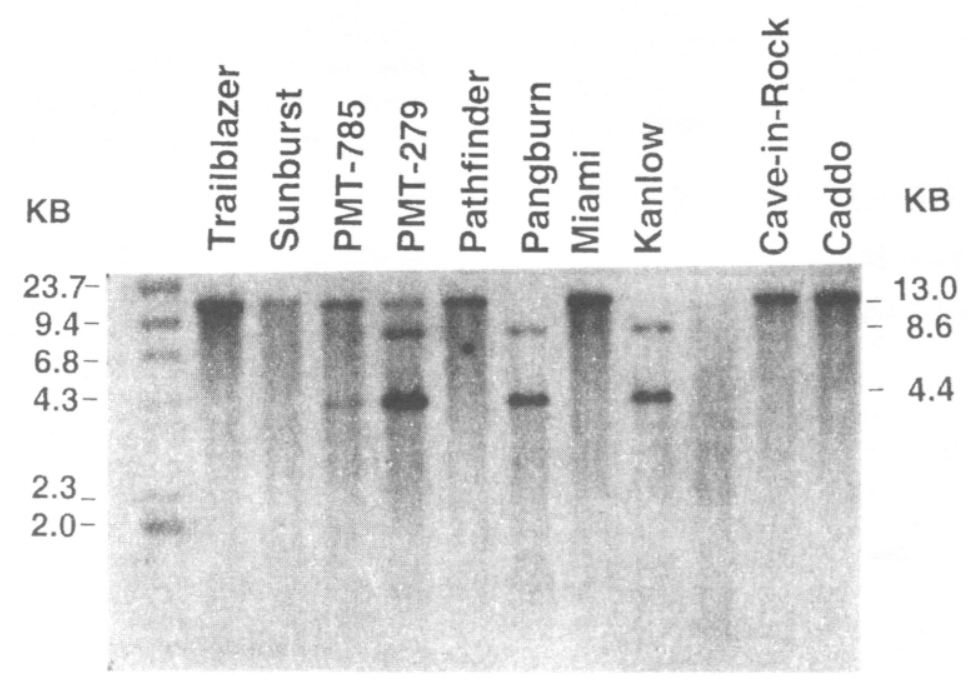

Fig. 1. Chloroplast DNA polymorphism among cultivars and experimental strains of switchgrass. The DNA was digested with restriction endonuclease BamHI and probed with sorghum cpDNA probe pLD5. HindIII-digested $\lambda$ DNA size markers are in the first lane and molecular weights of polymorphic bands are marked in kilobases (kb) on the far right. 
lowland ecotypes has not been reported in the literature. The cpDNA marker described in this report can now be used to identify $\mathrm{U}$ and $\mathrm{L}$ cytotypes as parents for reciprocal hybridization studies. The cpDNA of the progeny from these crosses will indicate the mode of plastid transmission in switchgrass. The number and the fertility of the hybrid progeny will provide information for determining if the upland (U) and lowland (L) ecotypes of switchgrass should remain classified as the same species.

\section{REFERENCES}

Alderson, J., and W.C. Sharp. 1994. Grass varieties in the United States. USDA-SCS Agric. Handb. 170. U.S. Gov. Print. Office, Washington, DC.

Arumuganathan, K., and E.D. Earle. 1991. Estimation of nuclear DNA contents of plants by flow cytometry. Plant Mol. Biol. Rep. 9:229-241.

Barnett, F.L., and R.F. Carver. 1967. Meiosis and pollen stainability in switchgrass, Panicum virgatum L. Crop Sci. 7:301-304.

Brunken, J.N., and J.R. Estes. 1975. Cytological variation in Panicum virgatum L. Southwestern Nat. 4:379-405.

Church, G.L. 1940. Cytotaxonomic studies in the Gramineae: Spartina, Andropogon, and Panicum. Am. J. Bot. 27:263-271.

Cornelius, P.I., and C.O. Johnston. 1941. Differences in plant type and reaction torust among several collections of Panicum virgatum L. J. Am. Soc. Agron. 33:115-124.

Dang, L.H., and D.R. Pring. 1986. A physical map of the sorghum chloroplast genome. Plant Mol. Biol. 6:119-123.

Eberhardt, S.A., and L.C. Newell. 1959. Variation in domestic collections of switchgrass, Panicum virgatum. Agron. J. 51:613616.

Elmore, S.J. 1995. Chloroplast DNA polymorphisms in Panicum virgatum L. and other Panicums L. Ph.D. diss. University of Nebraska, Lincoln.

Everett, H.W. 1991. Native perennial warm season grasses for forage in southeastern United States (except south Florida). USDA-SCS, Fort Worth, TX.

Laurent, V., A.M. Risterucci, and C. Lanaud. 1993. Chloroplast and mitochondrial DNA diversity in Theobroma cacoa. Theor. Appl. Genet. 87:81-88.

McMillan, C., and J. Weiler. 1959. Cytogeography of Panicum virgatum in central North America. Am. J. Bot. 46:590-593.

Moser, L.E., and K.P. Vogel. 1995. Switchgrass, big bluestem, and indiangrass. p. 409-420. In R.F Barners et al. (ed.) Forages: An introduction to grassland agriculture. 5th ed. Vol I. Iowa State Univ. Press, Ames, IA.

Neale, D.B., M.A. Saghai-Maroof, R.W. Allard, Q. Zhang, and R.A. Jorgensen. 1986. Chloroplast DNA diversity in populations of wild and cultivated barley. Genetics 120:1105-1110.

Newell, L.C., and S.A. Eberhardt. 1961. Clone and progeny evaluation in the improvement of switchgrass, Panicum virgatum L. Crop Sci. 1:117-121.

Nielson, E.L. 1944. Analysis of variation in Panicum virgatum. J. Agric. Res. 69:327-353.

Palmer, J.D. 1987. Chloroplast DNA evolution and biosystematic uses of chloroplast DNA variation. Am. Nat. 130:S6-S29.

Porter, C.L. 1966. An analysis of variations between upland and lowland switchgrass, $P$. virgatum L., in central Oklahoma. Ecology 47:980-992.

Reed, K.C., and D.A. Mann. 1985. Rapid transfer of DNA from agarose gels to nylon membranes. Nucleic Acid Res. 13:72077221.

Riley, R.D., and K.P. Vogel. 1982. Chromosome numbers of released cultivars of switchgrass, indiangrass, big bluestem, and sand bluestem. Crop Sci. 22:1082-1083.

Saghai-Maroof, M.A., K.M. Soliman, R.A. Jorgensen, and R.A. Allard. 1984. Ribosomal DNA spacer length polymorphism in barley: mendelian inheritance, chromosomal location, and population dynamics. Proc. Natl. Acad. Sci. (USA) 81:8014-8018.

Soltis, D.E., P.S. Soltis, and B.G. Milligan. 1992. Intraspecific chloroplast DNA variation: systematic and phylogenetic implications. p. 117-150. In P.S. Soltis et al. (ed.) Molecular systematics of plants. Chapman and Hall Publishers, New York.

Vogel, K.P., F.A. Haskins, H.J. Gorz, B.A. Anderson, and J.K. Ward. 1991. Registration of 'Trailblazer' switchgrass. Crop Sci. 31:1388. 